\title{
TITLE:
}

\section{CONTRIBUTIONS TO JAPANESE ASCIDIAN FAUNA XXIV. -ON SIGILLINARIA CLAVATA OKA, 1933-}

AUTHOR(S):

Tokioka, Takasi

\section{CITATION:}

Tokioka, Takasi. CONTRIBUTIONS TO JAPANESE ASCIDIAN FAUNA XXIV. -ON SIGILLINARIA CLAVATA OKA, 1933-. PUBLICATIONS OF THE SETO MARINE BIOLOGICAL LABORATORY 1968, 16(3): 199-205

ISSUE DATE:

1968-11-20

URL:

http://hdl.handle.net/2433/175543

RIGHT: 


\title{
CONTRIBUTIONS TO JAPANESE ASCIDIAN FAUNA XXIV. ON SIGILLINARIA CLAVATA OKA, 1933
}

\author{
TAKASI TOKIOKA
}

Seto Marine Biological Laboratory

With 2 Text-Figures

At the chance when I was asked for the exact identification of a complicatedly branched colony of a compound ascidian from an unknown locality, which belongs to the Biological Laboratory, Ycshida College of Kyoto University, I reviewed the genus Sigillinaria OKA, 1933 together with the type species of the genus, S. clavata OKA, 1933. Three other similar colonies which came from the king crab fishing ground off West Kamchatka were submitted to me for identification by the Zoological Institute of Hokkaido University. The structure of zooids from these four colonies was found quite the same as that of the zooids from a small piece of the OrA's type colony of Sigillinaria clavata. Then the original description of $S$. clavata was checked. The relation between the genera Ritterella and Sigillinaria was discussed and the resting stage of $S$. clavata was referred to.

\section{Sigillinaria clavata OKA, 1933}

OkA, A., 1933. Proc. Imp. Acad., 9 (2), pp. 78-81, 2 figs.

Ritterella clavala: Tокіока, 1963. Publ. Seto Mar. Biol. Lab., 11 (1), p. 133.

Material: No. 1: Loc. unknown, possibly the Tisima (Kurile) Islands; one colony. Sp. No. 3356, Biol. Lab., Yoshida Coll. Kyoto Univ.

No. 2: $55^{\circ} 46^{\prime} \mathrm{N} \times 155^{\circ} 11^{\prime} \mathrm{E}, 60 \mathrm{~m}$; June 4, 1959; Hokuhô-Maru coll., one colony.

No. 3: $56^{\circ} 16^{\prime} \mathrm{N} \times 155^{\circ} 09^{\prime} \mathrm{E}, 65 \mathrm{~m}$; August 19, 1959 ; Hokuhô-Maru coll., one colony.

No. 4: $55^{\circ} 27^{\prime} \mathrm{N} \times 155^{\circ} 12^{\prime} \mathrm{E}$; July 24,1957 ; the 5th Katsura-Maru coll., one colony.

No. 1 colony (Fig. $1 \mathrm{~A}$ ): About $14 \mathrm{~cm}$ long complicatedly branched colony. The colony consists of six branches attached to the common stem, about $7 \mathrm{~cm}$ long and 9-12 $\mathrm{mm}$ in diameter. Each branch, then, consists of a rather slender peduncle,

1) Contributions from the Seto Marine Biological Laboratory, No. 492.

Publ. Seto Mar. Biol. Lab., XVI (3), 199-205, 1968. (Article 15) 


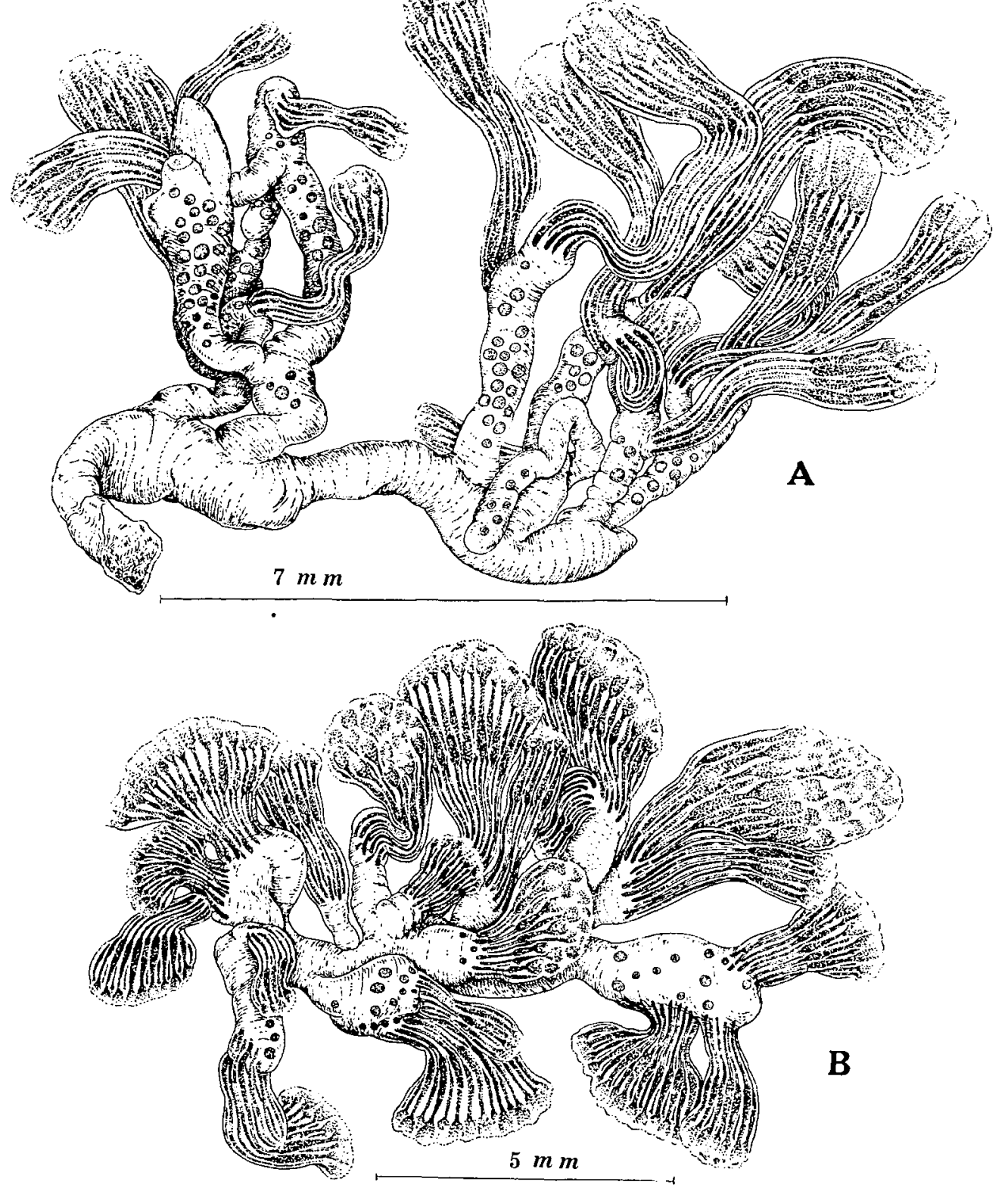

Fig. 1. Sigillinaria clavala.OKA, 1933. A: No. l colony with longer peduncles, from? Tisima (Kurile) Islands. B: No. 2 colony with shorter stout peduncles, from the king crab fishing ground off West Kamchatka. 


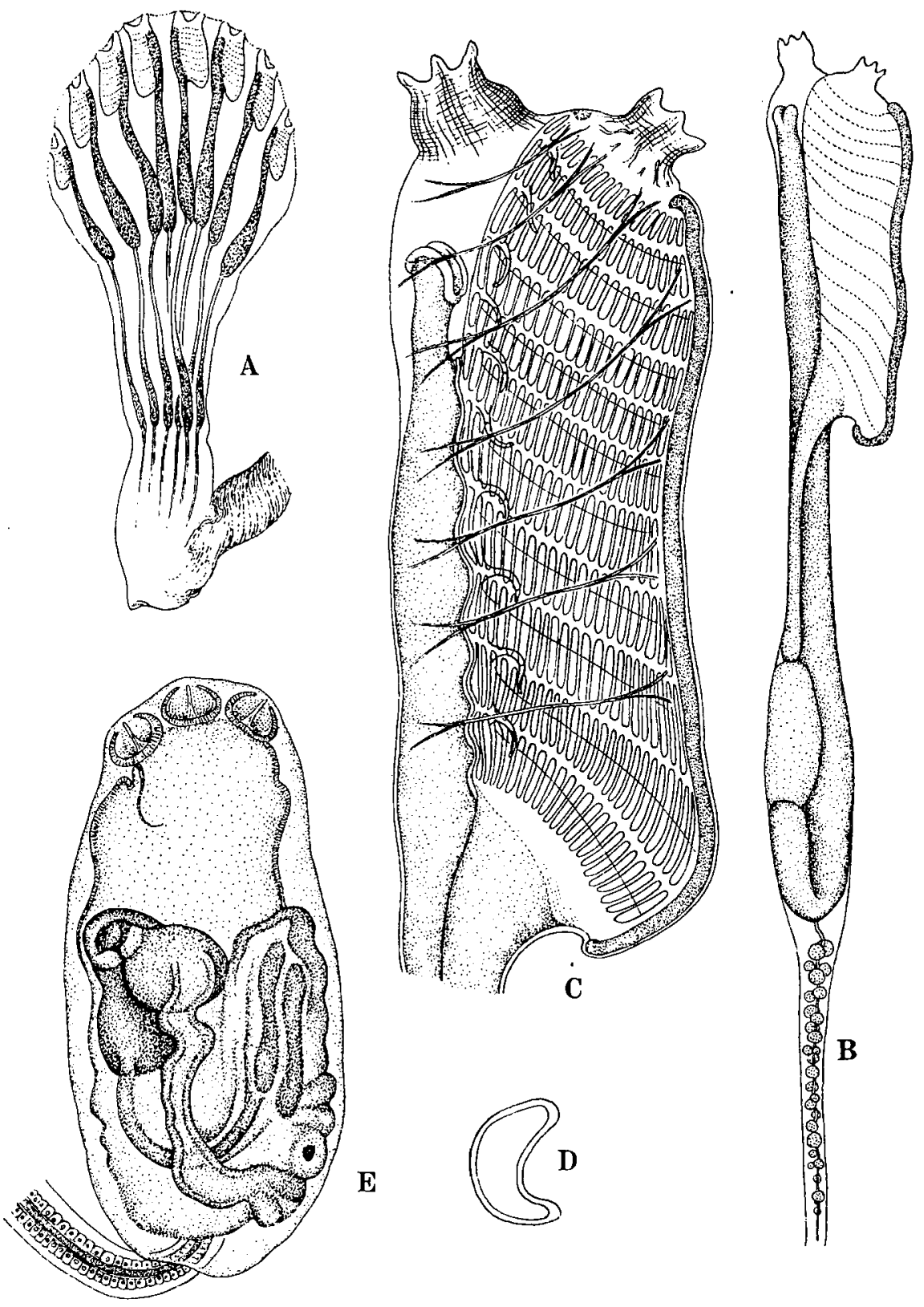

Fig. 2. Sigillinaria clavata OKA, 1933. A: Optical section of a cormidium. B: Right side of thorax, abdomen, and anterior portion of postabdomen. C: Right side of thorax. D: Cross section of stomach. E: Left side of embryo, $\times 73$. 
about $6 \mathrm{~mm}$ in diameter, and two or three cormidia. The cormidium is about $40 \mathrm{~mm}$ long, generally club-shaped; the largest one $45 \mathrm{~mm}$ long and $25 \mathrm{~mm}$ in diameter; zooids embedded with their ventral side towards the periphery (Fig. $2 \mathrm{~A}$ ). The common stem and peduncle are cartilaginous rather than gelatinous, milky white and translucent; the peduncles contain various numbers of somewhat pinkish spherical bodies, up to $2 \mathrm{~mm}$ in diameter. The proximal portion of the cormidium containing pinkish postabdomens is also faintly milky white, translucent, and rather hard. The middle portion of the cormidium containing abdomens becomes softer and transparent. The distal portion of the cormidium, the corona, which includes the thoraces is very soft and quite transparent. As the alimentary canal, exclusive of the oesophagus and stomach, but often together with the branchial sac, is packed with silt, the corona and the thoracic layer of the cormidium are coloured muddy. The colony surface is free from any foreign matters and nearly smooth.

The thorax (Fig. $2 \mathrm{C}$ ) is $5.5 \mathrm{~mm}$ to $7 \mathrm{~mm}$ in length, the adbomen is 9 to $12 \mathrm{~mm}$, and the postabdomen attains to $22 \mathrm{~mm}$, though sometimes it is only as long as the abdomen. Both the branchial and atrial apertures are six-lobed and open each directly to the exterior; in a considerably contracted state the atrial is always situated anterior to the level of the branchial. The exact arrangement of the thoracic muscles is uncertain, because of an unsatisfactory state of preservation, though at least several oblique or transverse muscles are clearly discernible.

Stigmatal rows are 11 to 13 , most frequently 11 to 12 ; probably 20 to 25 very elongate stigmata in each row on respective sides. The horizontal membrane is well developed, especially along several posterior transverse vessels; there the free margin of the membrane may attain the middle of the following stigmatal row when the membrane is flapped down. The dorsal languets are very slender and displaced in the posterior part of the branchial sac to the left side for several stigmata. OKA gave the tentacle formula as 6 large- 6 intermediate- 12 small, but in the present material smaller ones else than 6 (or 8 ) larger could not be counted exactly. The ciliated groove is a small elliptical opening. The distal end of the rectum is attached to the branchial sac nearly at the level of the sixth transverse vessel, but the anus which is distinctly bilobed is further protruded out anteriorly for two to three stigmatal rows so that the level of the anus approaches in a more or less contracted state the anterior end of the branchial sac. Several elongate embryos are found in the incubatory pouch on the right dorsal side of the thorax.

The abdomen (Fig. 2 B) is very slender. The oesophagus is thin, the posterior portion is slightly thickened and faintly pinkish. The stomach is elongate, the cardiac end begins approximately at the middle of the abdomen and the pyloric end is situated at the middle of the posterior half of the abdomen. It is pinkish orange and the surface is quite smooth. In cross section it is crescent-shaped, being concave on the side facing the intestine (Fig. 2 D). No other distinct junction was observed on the following part of the alimentary canal. The circum-intestinal gland was obscure in 
zooids of the present material.

The postabdomen (Fig. $2 \mathrm{~A}, \mathrm{~B}$ ) is very long and thin; the posterior portion is slightly swollen and packed with pinkish parenchymal tissue; a vascular vessel issued from the posterior end penetrates deep into the peduncle. A number of small ova, some of which, at least the posterior ones, might be testicular follicles, are found in the anterior portion in some zooids.

The embryos (Fig. 2 E) are elongate, $990 \mu$ long and $460 \mu$ wide (mean of $4 \mathrm{em}$ bryos). Three spherical attachment processes are sessile and arranged linearly; the pigment spot of the sensory organ is situated very posteriorly.

No. 2 colony (Fig. $1 \mathrm{~B}$ ): About $13 \mathrm{~cm}$ long colony, branched just similarly to the No. 1 colony. In this colony, however, the peduncles are very short and stout, and the spherical bodies which are very abundant in the No. 1 colony are distributed much more sparsely near the proximal end of the postabdominal layer of respective cormidia and somewhat smaller, about $1 \mathrm{~mm}$ in diameter. One to three, most frequently two to three cormidia are attached to each peduncle. The distal part of the cormidium including the corona and the thoracic layer is nearly spherical, clubshaped,or expanded to a fan-shape. The general appearance of the colony surface and the exact structure of the zooid are quite the same as those of the No. 1 colony. No. 3 and No. 4 colonies: These colonies assume the appearance of the No. 2 colony deprived of the soft distal part of respective cormidia. The spherical bodies embedded in the peduncle are much more numerous and become a little larger, up to $2 \mathrm{~mm}$ in diameter.

\section{Considerations}

The above-mentioned features agree exactly with the original description given by Oка (1933) only except the number of the stigmatal rows. According to Oka, "Bei fast allen Individuen konnte ich 16 Kiemenspaltenreihen zahlen" (p. 80). In spite of my efforts, no more stigmatal rows than 13 were observed. Very fortunately, it was found that a small piece of the type colony of $S$. clavata was in my hand. Though the state of preservation of zooids was not so good, the existence of 12 stigmatal rows was confirmed. As the free edge of the horizontal membranes cuts the stigmatal rows into the anterior and posterior halves when they are flapped down, it is not impossible that some posterior rows were counted under microscope twice as much. Most probably, however, 16 is a misprint for 12 .

The No. 1 colony reminded me of the Polycitoridae form B (PI. 25, fig. 34) from the king crab fishing ground off western Kamchatka (TokıокA, 1960). As the appearance of this Polycitoridae form $B$ resembles exactly that of the No. 1 colony deprived of the soft distal portion of cormidia, it may be accepted very safely that the Polycitoridae form $\mathrm{B}$ is nothing but the resting stage of $S$. clavata. OKA must notice this when he made the description of $S$. clavata as seen in some lines of his paper (p. 79)-“Die Einzeltiere sind auf die Köpfe beschränkt, während der Stiel derselben 
vollkommen entbehrt und nur hier und da zerstreut eingebettete kugelige Larvenknospen durchschimmern lässt". The Polycitoridae form A shown in TokiokA's same paper probably belongs to another species, as the branching feature and the appearance of branch tips are unique.

Huus (1937) treated the polyclinid referable to Sigillinaria Ока, 1933 under the genus Ritterella Harant, 1931 which was defined as "Polycliniden mit frei ausmündenden Atrialöffnungen. Magen mit Längsfalten. Kieme mit 8 KiemenspaltZonen, sonst wie Pseudodistoma" (pp. 667-668), with the type species Amaroucium aequali-siphonis RITTER \& FORSYTH, 1917. And VAN NAME (1945) applied the genus Sigillinaria for Distoma pulchra RITTER, 1901 and Amaroucium aequali-siphonis (pp. 73-75). I combined the opinions of HuUs and VAN NAME and showed $S$. clavata as Ritterella clavata (OKA) on the list of Japanese ascidians (TokıokA, 1963).

Really Distoma pulchra, Amaroucium aequali-siphonis, and Ritterella pedunculata Tokioka, 1953 from the northern North Pacific are provided with the stomach with very distinct longitudinal plications and thus they are properly referable to the genus Ritterella. However, this is very questionable about Sigillinaria clavata. One problem is whether or not the stomach of $S$. clavata can be regarded as longitudinally plicated. As shown in the description given above, the stomach of $S$. clavata is crescent-shaped in cross section, with two angles; otherwise the surface is quite smooth. These two angles are hardly regarded as longitudinal plications.

The other problem concerns the phylogenetic significance of the surface appearance of the ascidian stomach. As seen in series of species in genera Distaplia, Clavelina, and Ecteinascidia for instances, the feature of the stomach wall may differ considerably in the range from smooth to plicated even in the same genus. However, in the family Synoicidae the structure of the stomach wall is admitted as a very important criterion to separate the genus Synoicum from the genus Amaroucium. It cannot be judged easily whether this generic distinction is phylogenetic or arbitrary. Even if the latter is the case, the generic separation may be very useful in some cases for convenience'sake. Then, in the family Synoicidae, it might be recommendable to treat $S$. clavata separately from the group including $D$. pulchra, Am. aequali-siphonis, and $R$ : pedunculata. For this reason, it is proposed here that the genus Sigillinaria is defined as follows and retained as a valid genus distinct from Ritterella.

Sigillinaria: The stomach without longitudinal plications. Stigmatal rows more than 11 (as is seen in the known species). Otherwise quite like Ritterella and Pseudodistoma. Single species known; S. clavata which is distributed widely in the western subarctic region of the North Pacific, around Karahuto (Sakhalin), the Tisima (Kurile) Islands, and Kamchatka.

\section{REFERENCES}

Huus, J. (1937-40): Ascidiaceae in : Kükenthal \& Krumbach-Handbuch der Zoologie, Vol. 5, Part 2, Tunicata, pp. 545-692. 
Oка, A. (1933): U̇ber Sigillinaria, eine neue Synascidiengattung aus Nordpazifik. Proc. Imp. Acad., Vol. 9, No. 2, pp. 78-81, 2 figs.

TokıokA, T. (1953): Ascidians of Sagami Bay. Tokyo.

(1960): Contributions to Japanese ascidian fauna XVI. On some ascidians from the northern waters of Japan and the neighbouring subarctic waters. Publ. Seto Mar. Biol. Lab., Vol. 8, No. 1, pp. 191-204, Pls. 20-25.

(1963): Contributions to Japanese ascidian fauna XX. The outline of Japanese ascidian fauna as compared with that of the Pacific coasts of North America. Publ. Seto Mar. Biol. Lab., Vol. 11, No. 1, pp. 121-156.

VAN Name, W.G. (1945): The North and South American ascidians. Bull. American Mus. Nat. Hist., Vol. 84. 